\title{
ANALIZA STRUKTURALNA SIECI TRANSPORTOWEJ KOLEI WIELKOPOLSKICH
}

\author{
STRUCTURAL ANALYSIS OF KOLEJE WIELKOPOLSKIE \\ TRANSPORT NETWORK
}

\begin{abstract}
NR DOI: $10.25167 / \mathrm{sm} 2018.030 .04 \quad$ s. $57-70$
ABSTRAKT: Transport publiczny stanowi jeden z najważniejszych elementów rozwoju gospodarki oraz przestrzeni społecznej, na której występuje. W związku z tym bardzo istotne jest prawidłowe zorganizowanie oraz zaplanowanie sprawnej i odpornej na zakłócenia sieci transportowej, która umożliwi uzyskanie zakładanych celów stawianych przed transportem publicznym, zarówno tych gospodarczych, jak i społecznych. W artykule dokonano analizy strukturalnej - z wykorzystaniem teorii grafów - sieci kolejowej Kolei Wielkopolskich celem oceny jej struktury pod kątem organizacyjnym i funkcjonalnym. Sieć ta wykorzystywana jest m.in. do współrealizacji transportu zbiorowego w obrębie Aglomeracji Poznańskiej oraz okolicznych terenów.
\end{abstract}

SŁOWA KLUCZOWE: transport zbiorowy, transport kolejowy, sieci transportowe, Koleje Wielkopolskie

ABSTRACT: Public transport is one of the most important elements in the development of the economy and the social space in which it functions. It is therefore very important to properly organize and plan a smooth and resilient transport network that will meet the stated objectives of public transport, both economic and social. The article presents a structural analysis with the use of graph theory for the Koleje Wielkopolskie [Wielkopolskie Railways] railway network to assess its structure in terms of the organizational and functional aspects. The network is used, among others, in co-realization of the public transport within the Warsaw agglomeration and the surrounding areas.

KEY WORDS: public transport, railway transport, transport networks

\section{Wprowadzenie}

Zrównoważony transport jest obecnie jednym z najważniejszych elementów polityki prowadzonej przez Unię Europejską. Transport pełni bardzo ważną rolę w zakresie rozwoju gospodarki oraz społeczeństw zamieszkujących poszczególne obszary UE, dlatego na rozwój tej gałęzi gospodarki kładziony jest duży nacisk. Widoczne są również

\footnotetext{
* Akademia WSB w Dąbrowie Górniczej, Wydział Nauk Stosowanych, Katedra Inżynierii Zarządzania i Procesów Logistycznych, e-mail: psobczak@wsb.edu.pl
} 
skutki rozwoju tej gałęzi w poszczególnych krajach, zróżnicowanych zarówno pod kątem kulturowym, jak i pod względem zamożności społeczeństwa. W większości krajów europejskich (tych rozwiniętych i rozwijających się) zauważalny jest bardzo wysoki poziom wykorzystania transportu indywidualnego do realizacji codziennych podróży. Niesie to bardzo negatywne skutki społeczne i gospodarcze, szczególnie istotne w obszarze aglomeracji i okolicznych obszarów przyaglomeracyjnych - średnie napełnienie samochodu osobowego wynosi niestety tylko ok. 1,3 osoby (Jedź właściwym pasem...). Jest to bardzo niedobra sytuacja, niezgodna z założeniami tzw. Białej Księgi. Księga zakłada zwiększenie udziału transportu zbiorowego (z głównym naciskiem na transport zbiorowy „ekologiczny”, czyli szynowy i trolejbusowy) w miejsce indywidualnego (Biała Księga...). Zbyt duże wykorzystanie transportu indywidualnego oprócz powodowania negatywnych skutków ekonomicznych, społecznych i środowiskowych sprawia, że sieć transportu drogowego nie jest wykorzystywana w sposób optymalny. Jest to szczególnie widoczne oraz istotne w dużych aglomeracjach i obszarach aglomeracyjnych, gdzie zapewnienie sprawnego, szybkiego, bezpiecznego i odpornego na zakłócenia układu transportowego powinno stanowić jedno z priorytetowych zadań władz lokalnych odpowiedzialnych za kształtowanie sieci transportowej. Ma on za zadanie umożliwić w swoim obszarze przemieszczanie się dużej liczbie osób w tym samym czasie. Układ taki oprócz dostępności powinien charakteryzować się również odpornością na różne występujące w nim zakłócenia losowe - zarówno niezamierzone (np. awarie, wypadki drogowe), jak i zamierzone (np. ataki terrorystyczne).

Celem zwiększenia odporności na zakłócenia oraz by usprawnić transport, w aglomeracjach powinno się dążyć do realizacji przewozu osób w sposób zrównoważony, głównie poprzez wykorzystanie transportu zbiorowego. W Polsce nadal najpopularniejszym jego środkiem jest transport drogowy (głównie autobusowy), który niestety do realizacji swoich zadań wykorzystuje tą samą infrastrukturę co samochody indywidualne. Oprócz tej gałęzi w miastach wykorzystywany jest również transport szynowy (głównie tramwajowy), który wprawdzie na znacznych odcinkach posiada własną, niezależną infrastrukturę, jednak w wielu miejscach łączy się ona z infrastrukturą drogową i ewentualne zakłócenia w transporcie drogowym siłą rzeczy oddziałują również na transport tramwajowy.

Powyższe problemy w głównej mierze nie dotyczą innego rodzaju transportu szynowego - kolejowy, którego dodatkową zaletą są: duże zdolności przewozowe, niska szkodliwość dla środowiska, bezpieczeństwo oraz punktualność. Obecnie w Polsce, po kilkudziesięciu latach zapaści transportu kolejowego (również w obszarze aglomeracyjnym i miejskim), rozpoczęto jego ponowne wykorzystywanie do realizacji podróży w obrębie aglomeracji oraz obszarów miejskich i podmiejskich. Sieci aglomeracyjne, czy też sieci miejskie, powstały w każdej największej aglomeracji i konurbacji na terenie kraju.

Sieć tego typu na bazie infrastruktury kolejowej zarządzanej przez PKP Polskie Linie Kolejowe SA powstała również w województwie wielkopolskim. Została ona stworzona przez przewoźnika kolejowego Koleje Wielkopolskie. 


\section{Koleje Wielkopolskie}

Koleje Wielkopolskie to spółka, która została powołana 28 września 2009 r. przez samorząd województwa wielkopolskiego do realizacji przewozów kolejowych na terenie Wielkopolski, a swoją działalność przewozową rozpoczęła 1 czerwca 2011 r. Jedynym udziałowcem Kolei Wielkopolskich jest Samorząd Województwa Wielkopolskiego (Koleje Wielkopolskie...).

Według danych udostępnionych przez spółkę w roku 2015 na siedmiu liniach kolejowych o łącznej długości $644 \mathrm{~km}$ Koleje Wielkopolskie uruchomiły 45,5 tys. pociągów oraz przewiozły prawie 7,3 mln pasażerów. Do przewozu Koleje Wielkopolskie wykorzystują m.in. następujący tabor - w sumie 49 pojazdów kolejowych (Koleje Wielkopolskie. Raport Roczny 2015):

- elektryczne zespoły trakcyjne EN76 - ELF (22 szt.),

- elektryczne zespoły trakcyjne EN57Akw (6 szt.),

- spalinowe autobusy szynowe SA 108 (4 szt.),

- spalinowe autobusy szynowe SA 132 (11 szt.),

- spalinowe autobusy szynowe SA134 (2 szt.),

- spalinowe autobusy szynowe SA139 (4 szt.).

Oprócz wymienionego taboru wykorzystywane są również pojazdy pomocnicze itp. Schemat linii Kolei Wielkopolskich przedstawiono na ryc. 1.

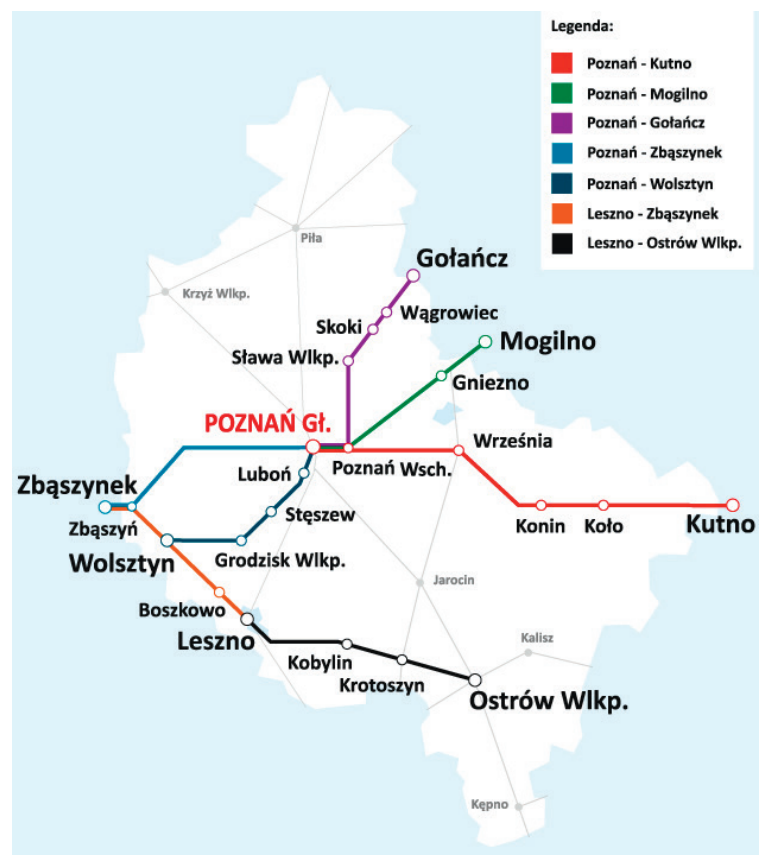

Ryc. 1. Schemat linii kolejowej Kolei Wielkopolskich Źródło: Koleje Wielkopolskie. Raport Roczny 2015. 
Jak przedstawiono na ryc. 1, Koleje Wielkopolskie swoim zasięgiem obejmują nie tylko teren Aglomeracji Poznańskiej, ale praktycznie obszar całego województwa (nie wliczając terenów w okolicy Piły). Jest to bardzo istotne, gdyż umożliwia podróżnym przemieszczanie się po terenie województwa z wykorzystaniem analizowanej gałęzi transportu (kolejowego) w zamian za chociażby transport indywidualny czy też zbiorowy samochodowy (głównie autobusowy). Jednak aby Koleje Wielkopolskie dobrze realizowały swoje zadania, ich działalność oprócz oferty częstych przejazdów na poszczególnych trasach oraz dbałości o atrakcyjność cen za świadczone usługi musi się również charakteryzować dobrze zorganizowaną siecią transportową, która zaprojektowana jest „pod pasażera”, czyli realizowane na niej połączenia powinny cechować: krótkie czasy przejazdu, krótkie odcinki tras - możliwość dojazdu z każdej i-tej stacji do każdej j-tej bez konieczności licznych przesiadek czy też „objazdów” po sieci wydłużających całą podróż oraz, co istotne, także odporność na ewentualne zakłócenia.

By ocenić strukturę sieci Kolei Wielkopolskich w aspekcie organizacyjnym i funkcjonalnym, dokonano analizy strukturalnej sieci przedstawionej na ryc. 1 pod kątem jej parametrów jako sieci transportowej. Wykorzystano teorię grafów. Przeprowadzona analiza miała na celu, oprócz oceny ogólnej sieci, wykazanie jej ewentualnych słabych punktów zarówno pod kątem aspektów organizacyjnych, jak i odporności na ewentualne zakłócenia.

\section{Metodologia przeprowadzonych badań}

Teoria grafów bardzo często wykorzystywana jest do analizy różnego rodzaju sieci. Głównie służy do analizy sieci społecznych (Amaral et al. 2000; Newman, Watts, Strogatz 2002; Arenas et al. 2000), jednak wykorzystywana jest także do analizy sieci neuronowych (Sporns 2002; Stam, Reijneveld 2007; Bullmore, Sporns 2000) czy też biologicznych (Rual et al. 2005). Możliwości analizy z wykorzystaniem teorii grafów opisanych wcześniej sieci przedstawił również M.E.J. Newman (2010). Teoria grafów może również być wykorzystana do analizy sieci sztucznych, stworzonych przez człowieka, czyli np. komputerowych (Valverde, Solé 2003) oraz - co istotne dla niniejszego opracowania - do analizy sieci transportowych (Newman 2010; Wilkinson, Dunn, Ma 2012; Li et al. 2014; Ouyang et al. 2015; Tarapata 2015). Teoria grafów pozwala na ocenę sieci transportowych pod kątem organizacyjnym i funkcjonalnym, ale jeżeli zostanie to połączone z analizą przestrzenną sieci, możliwe jest również wyciągnięcie wstępnych wniosków o odporności sieci na zakłócenia lub zagrożenia. Uzyskane z analizy informacje o typie sieci, czy też o roli poszczególnych węzłów w sieci, pozwalają wstępnie oszacować, które z punktów są szczególnie wrażliwe na potencjalne zagrożenia lub ataki (Newman 2010; Tarapata 2015). Większość ze stosowanych mierników oraz obliczeń pozwala także uzyskać informację, który z punktów (lub które punkty) sieci pełni główną rolę lub jest swoistym centrum analizowanej sieci. Według informacji 
zawartych w literaturze (Tarapata 2015) każda sieć może zostać opisana jako zbiór węzłów i powiązań pomiędzy nimi:

$$
G=\langle V, E\rangle
$$

gdzie:

$V$ - zbiór węzłów;

$E$ - zbiór powiązań pomiędzy węzłami.

Oczywiście dla każdej analizowanej sieci istnieje zależność, że:

$$
|V|=N,|E=M|
$$

gdzie:

$N$ - liczba węzłów w sieci;

$M$ - liczba powiązań pomiędzy węzłami.

Do najczęściej wykorzystywanych w teorii grafów wskaźników należą opisane szczegółowo w literaturze (Newman 2010; Tarapata 2015) następujące wskaźniki:

1) Stopień normalizacji (ang. normalized degree) $d c_{i} i$-tego węzła sieci:

$$
d c_{i}=\frac{k_{i}}{N-1}
$$

gdzie:

$k_{i}$ - stopień $i$-tego węzła w sieci (liczba połączeń węzła sieci z innymi węzłami);

$N$ - liczba węzłów w sieci.

Im większa jest wartość wskaźnika $d c_{i}$ dla $i$-tego węzła, tym ważniejszą funkcję węzeł ten pełni w sieci lub jest położony bliżej jej centrum.

2) Mimośrodowość (eccentricity) ec $i$-tego węzła sieci:

$$
e c_{i}=\max _{j \in V} d_{i j}
$$

gdzie:

$d_{i j}$ - liczba powiązań pomiędzy węzłami, która występuje na najkrótszej drodze pomiędzy węzłem $i$ oraz $j$.

Im wartość współczynnika ec ${ }_{i}$ dla $i$-tego węzła jest mniejsza, tym ważniejszą funkcję węzeł ten pełni w sieci lub jest położony bliżej jej centrum.

3) Promień zasięgu (radius) $r c_{i} i$-tego węzła sieci:

gdzie:

$$
r c_{i}=\frac{1}{\max _{j \in V} d_{i j}}=\frac{1}{e c_{i}}
$$

$d_{i j}$ - liczba powiązań pomiędzy węzłami, która występuje na najkrótszej drodze pomiędzy węzłem $i$ oraz $j$;

$e c_{i}$ - mimośrodowość $i$-tego węzła sieci. 
Im wartość współczynnika $r c_{i}$ dla $i$-tego węzła jest większa, tym ważniejszą funkcję węzeł ten pełni w sieci lub jest położony bliżej jej centrum.

4) Współczynnik bliskości (closeness) $c_{i}$ :

$$
c c_{i}=\frac{N-1}{\sum_{j \in V} d_{i j}}
$$

gdzie:

$N$ - liczba węzłów w sieci;

$d_{i j}$ - liczba powiązań pomiędzy węzłami, która występuje na najkrótszej drodze pomiędzy węzłem $i$ oraz $j$.

5) Współczynnik ważności/wagi (beetweeness) $b c_{i}$ i-tego węzła:

$$
b c_{i}=\sum_{l \in V} \sum_{k \neq l \in V} \frac{p_{l, i, k}}{p_{l, k}}
$$

gdzie:

$p_{l, i, k}$ - liczba połączeń o najkrótszej liczbie więzów pomiędzy węzłami $l$ i $k$ (zawierających węzeł $i$ );

$p_{l, k}$ - liczba połączeń o najkrótszej liczbie więzów pomiędzy węzłami $l$ i $k$ (niezawierających węzła $i$ ).

Im wartość współczynnika $b c_{i}$ dla $i$-tego węzła jest większa, tym ważniejszą funkcję węzeł ten pełni w sieci lub jest położony bliżej jej centrum.

6) Współczynnik klasteryzacji/grupowości (clusterization) $g c_{i} i$-tego węzła:

$$
g c_{i}=\frac{2 E_{i}}{k_{i}\left(k_{i}-1\right)}, \quad k_{i}>1
$$

gdzie:

$E_{i}$ - liczba wiązań pomiędzy węzłami, które są najbliżej (sąsiadami) $i$-tego węzła;

$k_{i}$ - stopień $i$-tego węzła w sieci (liczba połączeń węzła sieci z innymi węzłami).

Im wartość współczynnika $g c_{i}$ dla $i$-tego węzła jest większa, tym ważniejszą funkcję węzeł ten pełni w sieci lub jest położony bliżej jej centrum.

Obliczenie wartości powyższych wskaźników umożliwia ocenę zależności pomiędzy poszczególnymi węzłami sieci, jak również pozwala określić, z jakim typem sieci mamy do czynienia oraz który (lub też które) węzeł w sieci pełni dominującą rolę. Praktycznie nie występują w sieciach sytuacje, aby wszystkie węzły miały ten sam stopień „ważności”.

Każda sieć posiada węzły kluczowe, które bardziej niż inne są odpowiedzialne za prawidłowe funkcjonowanie całej sieci. Określenie tych węzłów oraz ich lokalizacji pozwala na wyciągnięcie wniosków na temat aktualnego stanu sieci oraz jej odporności na ewentualne zakłócenia. Informacje te również pozwalają na wprowadzenie bądź zaproponowanie usprawnień do analizowanej sieci. 


\section{Wyniki przeprowadzonych analiz}

Na podstawie ryc. 1 opracowano schemat sieci transportowej Kolei Wielkopolskich, który przedstawiono na ryc. 2. Opracowany schemat zawiera węzły przedstawione na schemacie linii kolejowej analizowanego przewoźnika.

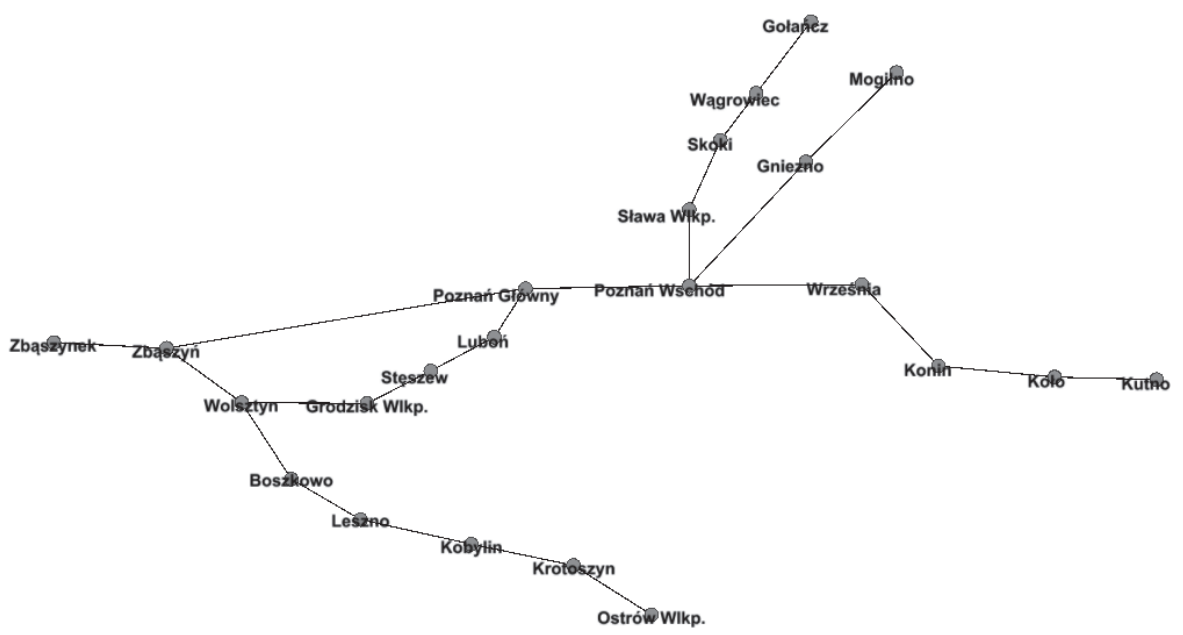

Ryc. 2. Układ sieci Kolei Wielkopolskich

Źródło: opracowanie własne na podstawie ryc. 1 z wykorzystaniem oprogramowania Gephi.

Uzyskany układ sieci zbudowany jest z 23 węzłów powiązanych ze sobą odpowiednimi relacjami, które odpowiadają układowi sieci Kolei Wielkopolskich. Na ryc. 2 przedstawiono tylko stacje występujące na schemacie opracowanym przez przewoźnika.

Dla uzyskanej sieci dokonano obliczeń parametrów opisanych w metodologii badań, a wyniki obliczeń przedstawiono w tabeli 1 .

Tabela 1

Wskaźniki poszczególnych węzłów sieci

\begin{tabular}{|l|c|c|c|c|c|c|c|}
\hline \multicolumn{1}{|c|}{ Miasto } & $\begin{array}{c}\text { Stopień } \\
\text { węzła } \\
k_{i}\end{array}$ & $\begin{array}{c}\text { Stopień } \\
\text { normali- } \\
\text { zacji } \\
d c_{i}\end{array}$ & $\begin{array}{c}\text { Mimo- } \\
\text { środo- } \\
\text { wość } \\
e c_{i}\end{array}$ & $\begin{array}{c}\text { Promień } \\
\text { zasięgu } \\
r c_{i}\end{array}$ & $\begin{array}{c}\text { Współczyn- } \\
\text { nik bliskości } \\
c c_{i}\end{array}$ & $\begin{array}{c}\text { Współ- } \\
\text { czynnik } \\
\text { ważności } \\
b c_{i}\end{array}$ & $\begin{array}{c}\text { Współczyn- } \\
\text { nik klaste- } \\
\text { ryzacji } \\
g c_{i}\end{array}$ \\
\hline Boszkowo & 2 & 0,091 & 8 & 0,125 & 0,232 & 0,312 & 0,000 \\
Gniezno & 2 & 0,091 & 9 & 0,111 & 0,244 & 0,091 & 0,000 \\
Gołańcz & 1 & 0,045 & 12 & 0,083 & 0,154 & 0,000 & 0,000 \\
Grodzisk Wlkp. & 2 & 0,091 & 8 & 0,125 & 0,222 & 0,043 & 0,000 \\
Kobylin & 2 & 0,091 & 10 & 0,100 & 0,173 & 0,173 & 0,000 \\
Koło & 2 & 0,091 & 11 & 0,091 & 0,180 & 0,091 & 0,000 \\
\hline
\end{tabular}


Tabela $1 \mathrm{~cd}$

\begin{tabular}{|l|c|c|c|c|c|c|c|}
\hline \multicolumn{1}{|c|}{ Miasto } & $\begin{array}{c}\text { Stopień } \\
\text { węzła } \\
k_{i}\end{array}$ & $\begin{array}{c}\text { Stopień } \\
\text { normali- } \\
\text { zacji } \\
d c_{i}\end{array}$ & $\begin{array}{c}\text { Mimo- } \\
\text { środo- } \\
\text { wość } \\
e c_{i}\end{array}$ & $\begin{array}{c}\text { Promień } \\
\text { zasięgu } \\
r c_{i}\end{array}$ & $\begin{array}{c}\text { Współczyn- } \\
\text { nik bliskości } \\
c c_{i}\end{array}$ & $\begin{array}{c}\text { Współ- } \\
\text { czynnik } \\
\text { ważności } \\
b c_{i}\end{array}$ & $\begin{array}{c}\text { Współczyn- } \\
\text { nik klaste- } \\
\text { ryzacji } \\
g c_{i}\end{array}$ \\
\hline Konin & 2 & 0,091 & 10 & 0,100 & 0,214 & 0,173 & 0,000 \\
Krotoszyn & 2 & 0,091 & 11 & 0,091 & 0,151 & 0,091 & 0,000 \\
Kutno & 1 & 0,045 & 12 & 0,083 & 0,154 & 0,000 & 0,000 \\
Leszno & 2 & 0,091 & 9 & 0,111 & 0,200 & 0,247 & 0,000 \\
Luboń & 2 & 0,091 & 8 & 0,125 & 0,253 & 0,082 & 0,000 \\
Mogilno & 1 & 0,045 & 10 & 0,100 & 0,198 & 0,000 & 0,000 \\
Ostrów Wlkp. & 1 & 0,045 & 12 & 0,083 & 0,132 & 0,000 & 0,000 \\
Poznań Główny & 3 & 0,136 & 7 & 0,143 & 0,314 & 0,550 & 0,000 \\
Poznań Wschód & 4 & 0,182 & 8 & 0,125 & 0,310 & 0,658 & 0,000 \\
Skoki & 2 & 0,091 & 10 & 0,100 & 0,214 & 0,173 & 0,000 \\
Sława Wlkp. & 2 & 0,091 & 9 & 0,111 & 0,256 & 0,247 & 0,000 \\
Stęszew & 2 & 0,091 & 7 & 0,143 & 0,234 & 0,043 & 0,000 \\
Wągrowiec & 2 & 0,091 & 11 & 0,091 & 0,180 & 0,091 & 0,000 \\
Wolsztyn & 3 & 0,136 & 7 & 0,143 & 0,268 & 0,407 & 0,000 \\
\hline Września & 2 & 0,091 & 9 & 0,111 & 0,256 & 0,247 & 0,000 \\
Zbąszynek & 1 & 0,045 & 7 & 0,143 & 0,229 & 0,000 & 0,000 \\
Zbąszyń & 3 & 0,136 & 6 & 0,167 & 0,293 & 0,442 & 0,000 \\
\hline
\end{tabular}

Źródło: opracowanie własne z wykorzystaniem oprogramowania Gephi.

Na podstawie wyników obliczeń przedstawionych w tabeli 1 wyraźnie widać, że głównymi węzłami sieci Kolei Wielkopolskich są stacje: Poznań Wschód, Poznań Główny i Wolsztyn oraz Zbąszyń. Na ryc. 3 i 4 przedstawiono graficznie rozkład przykładowych, obliczonych współczynników sieci - im większa średnica okręgu oraz większe natężenie koloru, tym wartość współczynnika dla danego węzła jest większa. Wizualizację danych przeprowadzono z wykorzystaniem oprogramowania Gephi.

Następnie dokonano obliczeń dla sieci składającej się tylko z węzłów oraz punktów końcowych sieci (pominięto stacje pośrednie). Sieć składającą się tylko z węzłów oraz punktów końcowych przedstawiono na ryc. 5.

Natomiast w tabeli 2 przedstawiono wyniki uzyskane dla sieci uwzględniającej tylko stacje węzłowe i końcowe.

Jak przedstawiono w tabeli 2, dla sieci składającej się tylko ze stacji węzłowych oraz końcowych najważniejszą rolę również pełnią stacje: Poznań Wschód, Poznań Główny oraz Wolsztyn i Zbąszyń.

W celu poprawy parametrów struktury sieci zaproponowano następnie wprowadzenie w analizowaną sieć istniejących linii kolejowych zarządzanych przez PKP PLK SA 


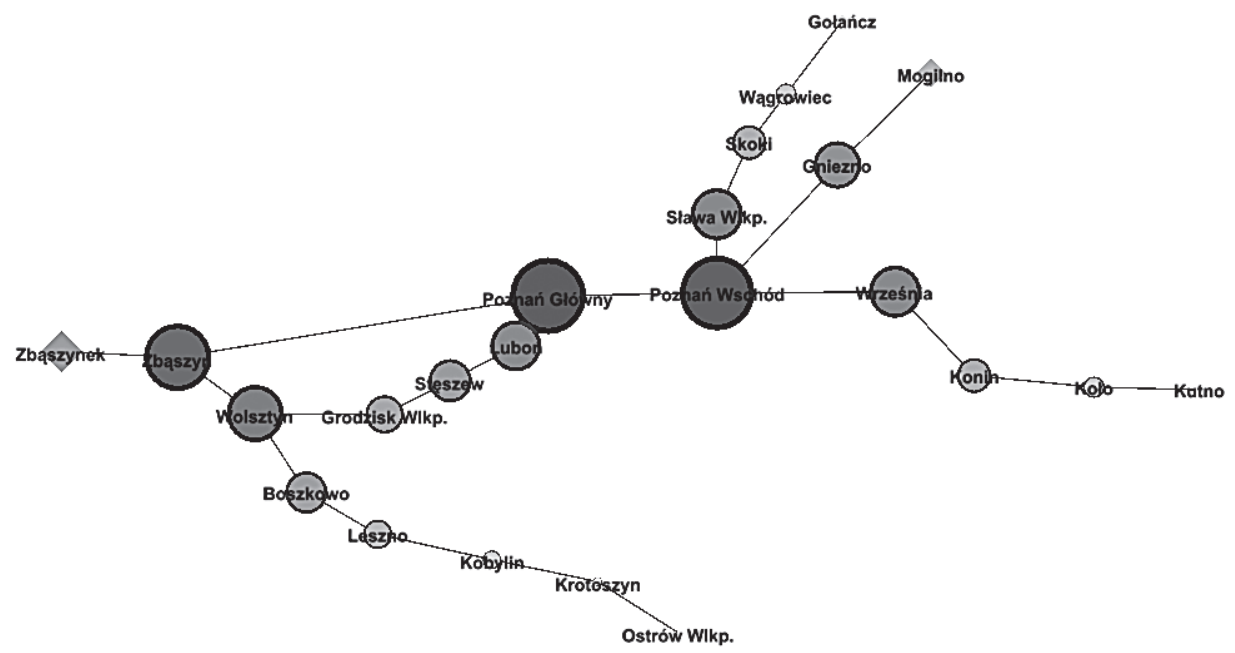

Ryc. 3. Współczynnik bliskości analizowanej sieci Kolei Wielkopolskich

Źródło: opracowanie własne.

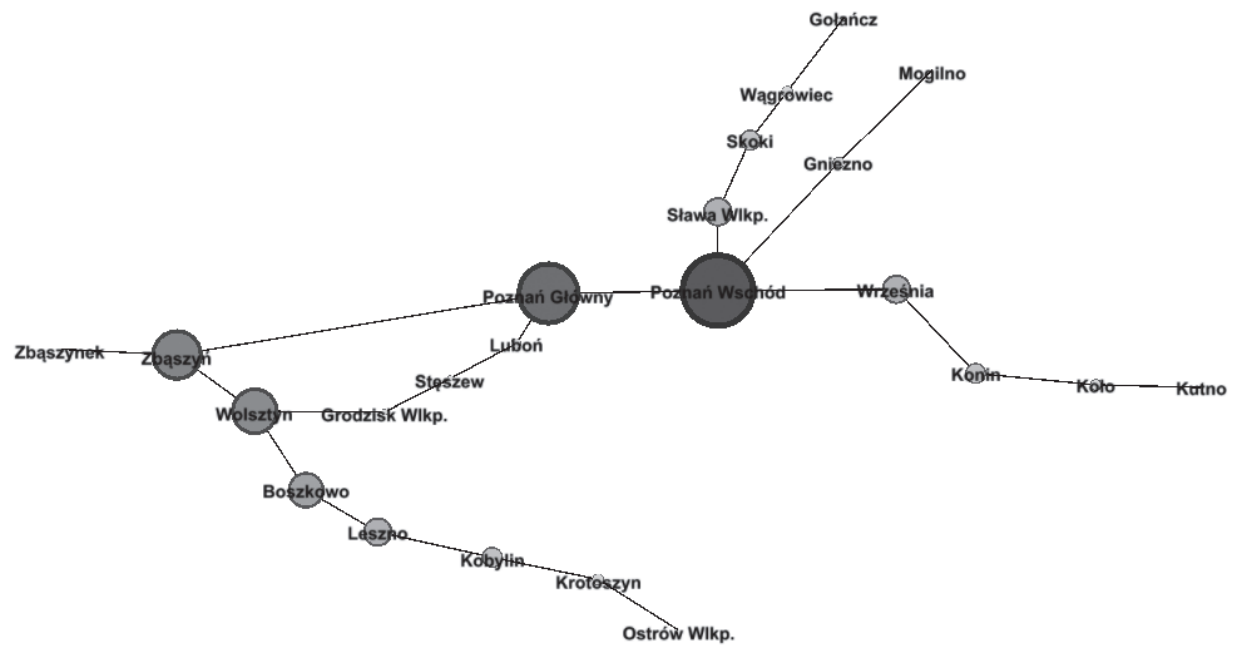

Ryc. 4. Współczynnik ważności analizowanej sieci Kolei Wielkopolskich Źródło: opracowanie własne.

znajdujących się na analizowanym obszarze. Zaproponowane nowe elementy sieci to stacja Jarocin i jej połączenia ze stacjami: Poznań Główny, Krotoszyn, Ostrów Wielkopolski, Września oraz dodatkowe połączenie pomiędzy Poznaniem Głównym a Lesznem, jak również dodatkowe połączenie Gniezno-Września. Nadrzędnym celem analizy było zaobserwowanie wpływu dodania nowych możliwości połączeń pomiędzy już istniejącymi węzłami sieci, a nie dodawanie kolejnych stacji do jej struktury - z tego 


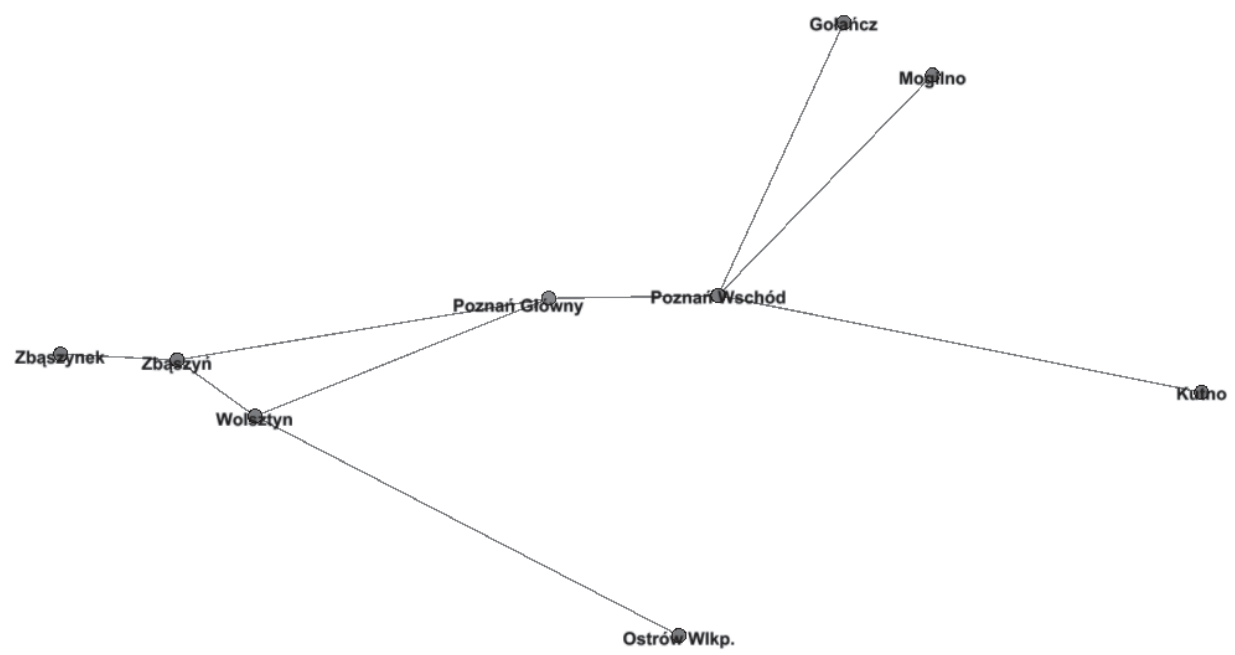

Ryc. 5. Układ sieci Kolei Wielkopolskich uwzględniający tylko stacje węzłowe i końcowe

Źródło: opracowanie własne na podstawie ryc. 2 z wykorzystaniem oprogramowania Gephi.

Tabela 2

Wskaźniki poszczególnych węzłów sieci dla sieci uwzględniającej tylko stacje węzłowe i końcowe

\begin{tabular}{|l|c|c|c|c|c|c|c|}
\hline \multicolumn{1}{|c|}{ Miasto } & $\begin{array}{c}\text { Stopień } \\
\text { węzła } \\
k_{i}\end{array}$ & $\begin{array}{c}\text { Stopień } \\
\text { normali- } \\
\text { zacji } \\
d c_{i}\end{array}$ & $\begin{array}{c}\text { Mimo- } \\
\text { środo- } \\
\text { wość } \\
e c_{i}\end{array}$ & $\begin{array}{c}\text { Promień } \\
\text { zasięgu } \\
r c_{i}\end{array}$ & $\begin{array}{c}\text { Współczyn- } \\
\text { nik bliskości } \\
c c_{i}\end{array}$ & $\begin{array}{c}\text { Współ- } \\
\text { czynnik } \\
\text { ważności } \\
b c_{i}\end{array}$ & $\begin{array}{c}\text { Współczyn- } \\
\text { nik klaste- } \\
\text { ryzacji } \\
g c_{i}\end{array}$ \\
\hline Gołańcz & 1 & 0,125 & 4 & 0,250 & 0,381 & 0 & 0,000 \\
Kutno & 1 & 0,125 & 4 & 0,250 & 0,381 & 0 & 0,000 \\
Mogilno & 1 & 0,125 & 4 & 0,250 & 0,381 & 0 & 0,000 \\
Ostrów Wlkp. & 1 & 0,125 & 4 & 0,250 & 0,348 & 0 & 0,000 \\
Poznań Główny & 3 & 0,375 & 2 & 0,500 & 0,615 & 16 & 0,333 \\
Poznań Wschód & 4 & 0,500 & 3 & 0,333 & 0,571 & 18 & 0,000 \\
Wolsztyn & 3 & 0,375 & 3 & 0,333 & 0,500 & 7 & 0,333 \\
\hline Zbąszynek & 1 & 0,125 & 4 & 0,250 & 0,348 & 0 & 0,000 \\
\hline Zbąszyń & 3 & 0,375 & 3 & 0,333 & 0,500 & 7 & 0,333 \\
\hline
\end{tabular}

Źródło: opracowanie własne na podstawie ryc. 5.

powodu m.in. nie zaproponowano dołączenia do sieci połączeń Kolei Wielkopolskich stacji Piła czy Krzyż Wielkopolski. Proponowaną sieć, uwzględniającą wprowadzone modyfikacje, przedstawiono na ryc. 6.

W tabeli 3 przedstawiono uzyskane wyniki obliczeń parametrów proponowanej sieci transportowej Kolei Wielkopolskich. 


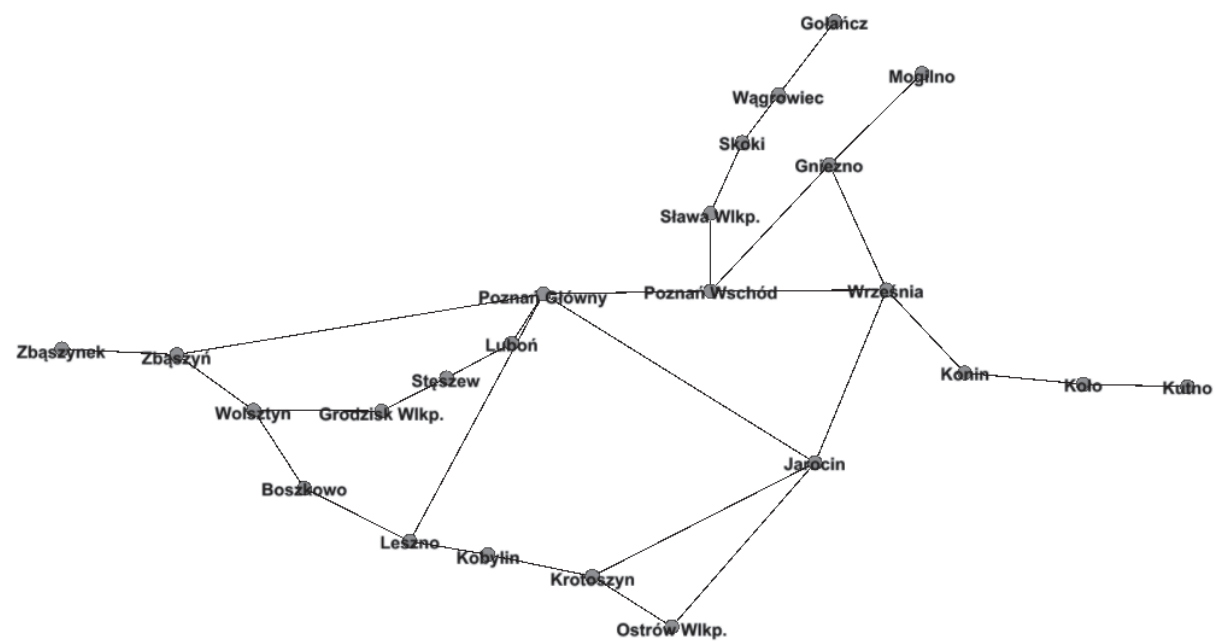

Ryc. 6. Układ sieci Kolei Wielkopolskich uwzględniający stacje i połączenia zaproponowane przez autora Źródło: opracowanie własne na podstawie ryc. 1 z wykorzystaniem oprogramowania Gephi.

Analogicznie jak dla oryginalnej sieci Kolei Wielkopolskich, dokonano wizualizacji graficznej przykładowych współczynników poszczególnych węzłów sieci - dla sieci zmodyfikowanej o węzeł i połączenia zaproponowane przez autora. Wizualizacje przedstawiono na ryc. 7 i 8.

Jak przedstawiono w tabeli 3, stacje Poznań Wschód, Poznań Główny oraz Zbąszyń nadal stanowią istotne węzły analizowanej sieci. Wprowadzenie nowego węzła kolejowego w postaci stacji Jarocin oraz jej połączeń ze stacjami ościennymi spowodowało, że rola węzła Wolsztyn w sieci uległa zmniejszeniu.

Tabela 3

Wskaźniki węzłów dla proponowanej sieci Kolei Wielkopolskich

\begin{tabular}{|l|c|c|c|c|c|c|c|}
\hline \multicolumn{1}{|c|}{ Miasto } & $\begin{array}{c}\text { Stopień } \\
\text { węzła } \\
k_{i}\end{array}$ & $\begin{array}{c}\text { Stopień } \\
\text { normali- } \\
\text { zacji } \\
d c_{i}\end{array}$ & $\begin{array}{c}\text { Mimo- } \\
\text { środo- } \\
\text { wość } \\
e c_{i}\end{array}$ & $\begin{array}{c}\text { Promień } \\
\text { zasięgu } \\
r c_{i}\end{array}$ & $\begin{array}{c}\text { Współczyn- } \\
\text { nik bliskości } \\
c c_{i}\end{array}$ & $\begin{array}{c}\text { Współ- } \\
\text { czynnik } \\
\text { ważności } \\
b c_{i}\end{array}$ & $\begin{array}{c}\text { Współczyn- } \\
\text { nik klaste- } \\
\text { ryzacji } \\
g c_{i}\end{array}$ \\
\hline Boszkowo & 2 & 0,087 & 7 & 0,143 & 0,271 & 4,833 & 0,000 \\
Gniezno & 3 & 0,130 & 5 & 0,200 & 0,329 & 22,000 & 0,333 \\
Gołańcz & 1 & 0,043 & 8 & 0,125 & 0,173 & 0,000 & 0,000 \\
Grodzisk Wlkp. & 2 & 0,087 & 8 & 0,125 & 0,225 & 3,500 & 0,000 \\
Jarocin & 4 & 0,174 & 6 & 0,167 & 0,371 & 59,167 & 0,167 \\
Kobylin & 2 & 0,087 & 7 & 0,143 & 0,277 & 3,833 & 0,000 \\
Koło & 2 & 0,087 & 7 & 0,143 & 0,225 & 22,000 & 0,000 \\
Konin & 2 & 0,087 & 6 & 0,167 & 0,280 & 42,000 & 0,000 \\
\hline
\end{tabular}


Tabela $3 \mathrm{~cd}$.

\begin{tabular}{|c|c|c|c|c|c|c|c|}
\hline Miasto & $\begin{array}{c}\text { Stopień } \\
\text { węzła } \\
k_{i}\end{array}$ & $\begin{array}{c}\text { Stopień } \\
\text { normali- } \\
\text { zacji } \\
d c_{i}\end{array}$ & $\begin{array}{l}\text { Mimo- } \\
\text { środo- } \\
\text { wość } \\
\quad e c_{i}\end{array}$ & $\begin{array}{c}\text { Promień } \\
\text { zasięgu } \\
r c_{i}\end{array}$ & $\begin{array}{l}\text { Współczyn- } \\
\text { nik bliskości } \\
\qquad c c_{i}\end{array}$ & $\begin{array}{l}\text { Współ- } \\
\text { czynnik } \\
\text { ważności } \\
b c_{i}\end{array}$ & $\begin{array}{l}\text { Współczyn- } \\
\text { nik klaste- } \\
\text { ryzacji } \\
g c_{i}\end{array}$ \\
\hline Krotoszyn & 3 & 0,130 & 7 & 0,143 & 0,291 & 8,000 & 0,333 \\
\hline Kutno & 1 & 0,043 & 8 & 0,125 & 0,185 & 0,000 & 0,000 \\
\hline Leszno & 3 & 0,130 & 6 & 0,167 & 0,329 & 30,833 & 0,000 \\
\hline Luboń & 2 & 0,087 & 6 & 0,167 & 0,315 & 25,333 & 0,000 \\
\hline Mogilno & 1 & 0,043 & 6 & 0,167 & 0,250 & 0,000 & 0,000 \\
\hline Ostrów Wlkp. & 2 & 0,087 & 7 & 0,143 & 0,280 & 0,000 & 1,000 \\
\hline Poznań Główny & 5 & 0,217 & 5 & 0,200 & 0,418 & 134,167 & 0,000 \\
\hline Poznań Wschód & 4 & 0,174 & 4 & 0,250 & 0,404 & 113,000 & 0,167 \\
\hline Skoki & 2 & 0,087 & 6 & 0,167 & 0,253 & 42,000 & 0,000 \\
\hline Sława Wlkp. & 2 & 0,087 & 5 & 0,200 & 0,315 & 60,000 & 0,000 \\
\hline Stęszew & 2 & 0,087 & 7 & 0,143 & 0,256 & 8,833 & 0,000 \\
\hline Wągrowiec & 2 & 0,087 & 7 & 0,143 & 0,207 & 22,000 & 0,000 \\
\hline Wolsztyn & 3 & 0,130 & 7 & 0,143 & 0,274 & 16,667 & 0,000 \\
\hline Września & 4 & 0,174 & 5 & 0,200 & 0,359 & 74,500 & 0,167 \\
\hline Zbąszynek & 1 & 0,043 & 7 & 0,143 & 0,250 & 0,000 & 0,000 \\
\hline Zbąszyń & 3 & 0,130 & 6 & 0,167 & 0,329 & 44,333 & 0,000 \\
\hline
\end{tabular}

Źródło: opracowanie własne na podstawie ryc. 3.

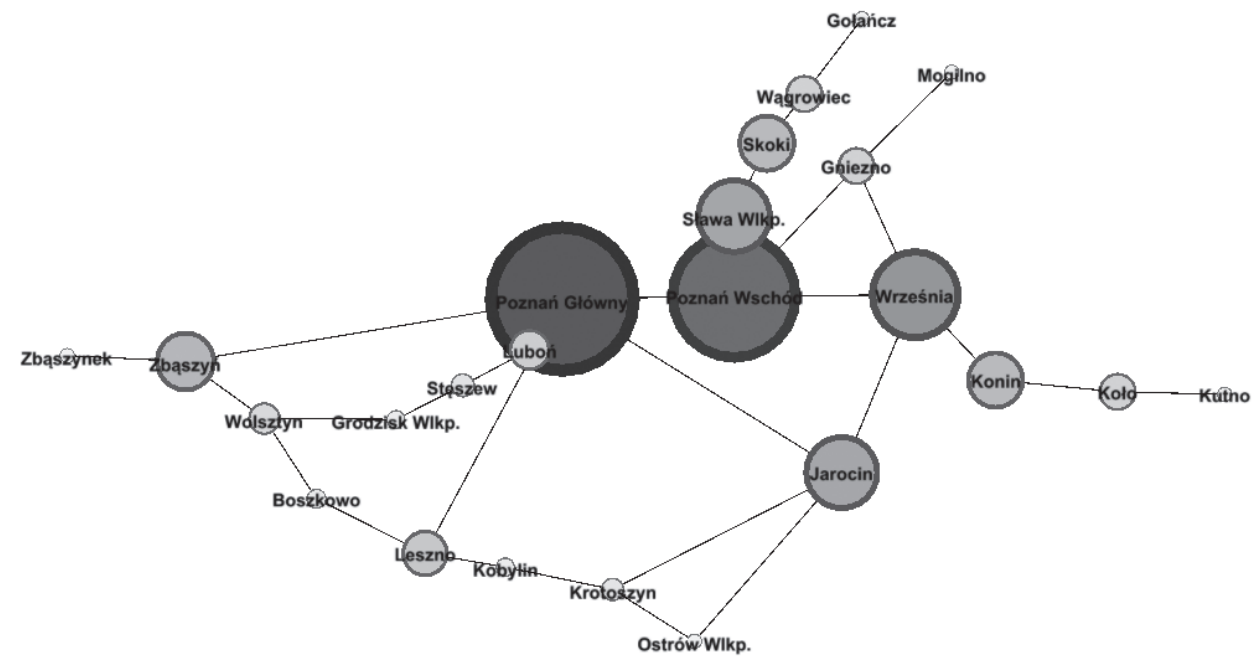

Ryc. 7. Współczynnik bliskości sieci Kolei Wielkopolskich zaproponowanej przez autora

Źródło: opracowanie własne z wykorzystaniem oprogramowania Gephi. 


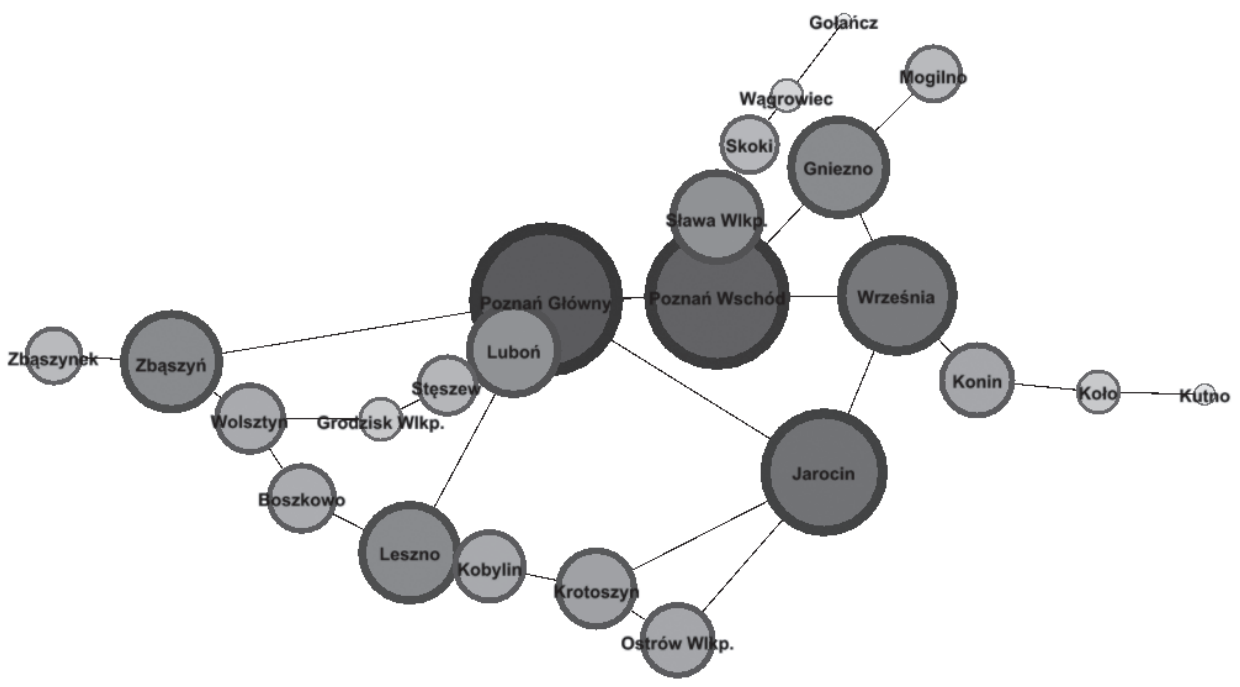

Ryc. 8. Współczynnik ważności analizowanej sieci Kolei Wielkopolskich

Źródło: opracowanie własne z wykorzystaniem oprogramowania Gephi.

\section{Podsumowanie}

Sieci transportu kolejowego mogą i powinny stanowić istotny element układu transportowego aglomeracji. Według przedstawionych w artykule informacji już teraz transport kolejowy umożliwia realizację podróży znacznej liczbie pasażerów. Biorąc pod uwagę wspomniane wyżej pozytywne cechy tej gałęzi transportu (dla realizacji transportu w aglomeracji są to przede wszystkim: ekologiczność, bezpieczeństwo i punktualność), jej rola w transporcie zrównoważonym powinna systematycznie rosnąć.

Sieć Kolei Wielkopolskich w obecnym stanie, zdaniem autora, nie posiada zbyt optymalnego układu. Uzyskane wyniki analiz wykazały, że główne węzły sieci zlokalizowane są w jej swoistym centrum (Poznań Wschód, Poznań Główny, Wolsztyn, Zbąszyń), natomiast rola stacji oddalonych od tych stacji jest zdecydowanie niższa, a dominującą rolę w sieci pełnią stacje Poznań Wschód oraz Poznań Główny (ryc. 3 i 4).

Zaproponowana przez autora zmiana polegająca na włączeniu w strukturę sieci stacji Jarocin oraz jej połączeń ze stacjami ościennymi spowodowała, że rozkład współczynników ważności sieci jest bardziej równomierny. Wprawdzie stacje Poznań Wschód i Poznań Główny nadal zachowały swoją dominującą rolę, jednak rola nowej stacji w sieci (Jarocin) jest również dosyć istotna oraz znacznie wzrosła rola pozostałych węzłów w sieci.

Może to stanowić pretekst do rozważenia, czy modyfikacja sieci i wprowadzenie połączeń przez Jarocin nie poprawią efektu ekonomicznego działalności przedsiębiorstwa oraz - co najbardziej istotne - czy nie przyczyni się do zwiększenia roli tej 
gałęzi transportu w układzie transportowym regionu. Oczywiście ewentualne decyzje związane z modyfikacją sieci powinny zostać poprzedzone wnikliwymi analizami możliwości technicznych i prognoz stopnia wykorzystania nowych połączeń przez potencjalnych podróżnych.

\section{Bibliografia}

Amaral L., Scala A., Barthelemy M., Stanley H., 2000, Classes of small-world networks, "Proceedings of the National Academy of Sciences of the USA" 97(21).

Arenas A., Danon L., Diaz-Guilera A., Gleiser P.M., Guimera R., 2000, Community analysis in social networks, "The European Physical Journal B" 38(2).

Bullmore E., Sporns O., 2000, Complex brain networks: graph theoretical analysis of structural and functional systems, "Nature Reviews Neuroscience" 10(3).

Li H., Guo X.M., Xu Z., Hu X.B., 2014, A study on the spaital vulnerability of the civil aviation network system in China, [w:] Proceedings of the IEEE 17th international conference on intelligent transportation systems, Qingdao.

Newman M.E.J., 2010, Networks: An introduction, Oxford University Press, New York.

Newman M.E.J., Watts D.J., Strogatz S.H., 2002 Random graph models of social networks, "Proceedings of the National Academy of Sciences of the USA" 99.

Ouyang M., Pan Z., Hong L., He Y., 2015, Vulnerability analysis of complementary transportation systems with applications to railway and airline systems in China, "Reliability Engineering \& System Safety" 142.

Rual J.-F., Venkatesan K., Hao T., Hirozane-Kishikawa T., Dricot A., Li N., Berriz G.F., Gibbons F.D., Dreze M., Ayivi-Guedehoussou N., Klitgord N., Simon C., Boxem M., Milstein S., Rosenberg J., Goldberg D.S., Zhang L.V., Wong S.L., Franklin G., Li S., Albala J.S., Lim J., Fraughton C., Llamosas E., Cevik S., Bex C., Lamesch P., Sikorski R.S., Vandenhaute J., Zoghbi H.Y., Smolyar A., Bosak S., Sequerra R., Doucette-Stamm L., Cusick ME., Hill D.E., Roth F.P., Vidal M., 2005, Towards a proteome-scale map of the human protein-protein interaction network, "Nature" 437(7062).

Sporns O., 2002, Network analysis, complexity, and brain function, "Complexity" 8(1).

Stam C.J., Reijneveld J.C., 2007, Graph theoretical analysis of complex networks in the brain, "Nonlinear Biomedicl Physics" 1(3).

Tarapata Z., 2015, Modelling and analysis of transportation networks using complex networks: Poland case study, "Archives of Transport" vol. 36, Is. 4.

Valverde S., Solé RV., 2003, Hierarchical small worlds in software architecture, https://arxiv.org/pdf/cond-mat/0307278.pdf (dostęp 14 kwietnia 2017).

Wilkinson S., Dunn S., Ma S., 2012, The vulnerability of the European air traffic network to spatial hazards, "Natural Hazards" 60(3).

Biała Księga - Plan utworzenia jednolitego europejskiego obszaru transportu - dążenie do osiągnięcia konkurencyjnego i zasobooszczędnego systemu transportu, http://europa.eu/documentation/official-docs/ white-papers/index_pl.htm (dostęp 4 października 2013).

Jedź właściwym pasem, http://siskom.waw.pl/kp-buspas1.htm (dostęp 2 sierpnia 2016).

Koleje Wielkopolskie. Raport Roczny 2015, http://koleje-wielkopolskie.com.pl/roczne-raporty/ (dostęp 14 kwietnia 2017).

Koleje Wielkopolskie, http://pl.wikipedia.org/wiki/Koleje_Wielkopolskie (dostęp 14 kwietnia 2017). 